\title{
AOTs and Solar Energy for Air, Water and Soil Treatment
}

\author{
Joanna Pawłat $^{1 *}$, Henryka Stryczewska ${ }^{1}$, Kenji Ebihara ${ }^{2}$ Fumiaki Mitsugi ${ }^{3}$, Ta-Lun Sung ${ }^{4}$ \\ 1 Lublin University of Technology, \\ Nadbystrzycka St. 38A, 20-618 Lublin, Poland \\ 2 Environment and Energy Laboratory, \\ Ohtemon 1-4-15-404 Chuouku, 810-0074 Fukuoka, Japan \\ 3 Kumamoto University, \\ 2-39-1 Kurokami Kumamoto, 860-8555 Japan \\ 4 Lunghwa University of Science and Technology, \\ No.300,Sec.1,Wanshou Rd.,Guishan, Taoyuan County 33306, Taiwan \\ * Corresponding author e-mail: askmik@hotmail.com
}

In many locations, generation of electrical energy is restricted due to unfavorable logistic conditions. That limits introduction of new technologies, requiring electrical power including air, water and soil purification technologies. Small scale treatment installations supplied with electric energy from solar sources were proposed as a good example of zero-emission technology achieved with reasonable cost. Treatment process of agricultural samples, pathogens and pests based on ozone and advanced oxidation process was described.

Key words: solar energy, ozone treatment, AOT, agricultural management

\section{INTRODUCTION}

Possibility of solar energy application, as one of the alternative energy resources for decontamination processes of air, water and soil is strongly dependent on geographical location. Constant growth of fuel prices in the last decade caused rapid development of solar technology across Europe, including its northern parts.

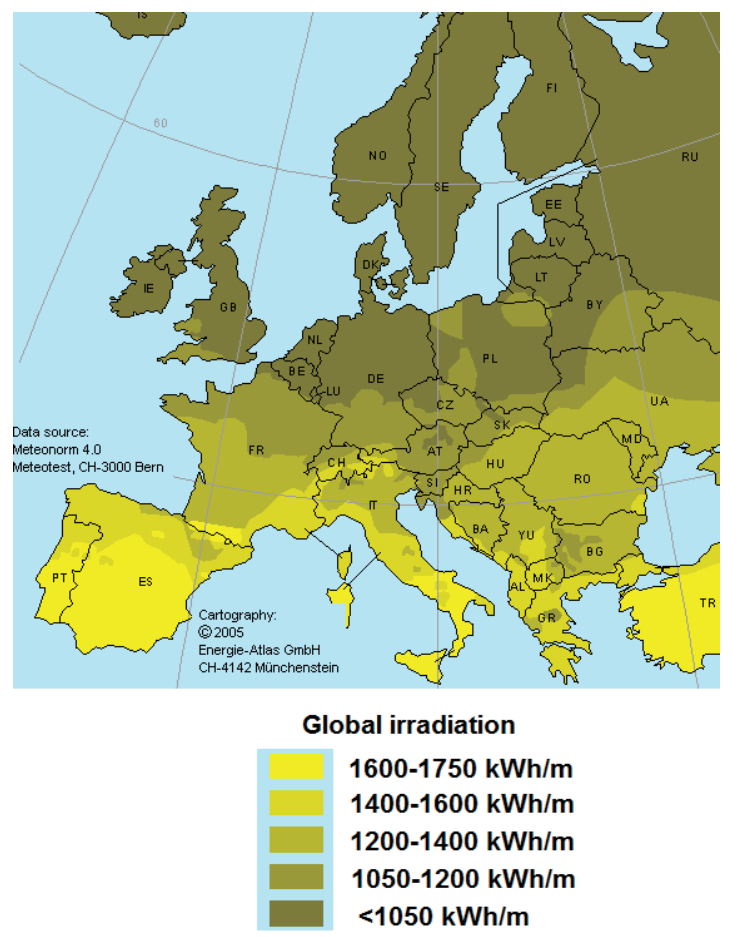

Fig. 1. Global irradiation - Europe [1]
The average annual insolation on Europe is depicted in Fig. 1. Poland's territory amounts to about $1100 \mathrm{kWh} / \mathrm{m}^{2}$ $\left(3500 \mathrm{MJ} / \mathrm{m}^{2}\right)$ per year on a horizontal area, which corresponds to the calorific value of $120 \mathrm{~kg}$ of theoretical standard fuel $(29300 \mathrm{~kJ} / \mathrm{kg}$ of hard coal, $41860 \mathrm{~kJ} / \mathrm{kg}$ of petroleum). Insolation on Poland is characterized by a big annual diversification. For example, the annual amount for the Lublin city is about $1107 \mathrm{kWh}$, and while over $15 \%$ of annual energy reaches Lublin in August, in December it is only 1,6\%. The typical daily insolation in Lublin area in Summer is presented in Fig. 2.

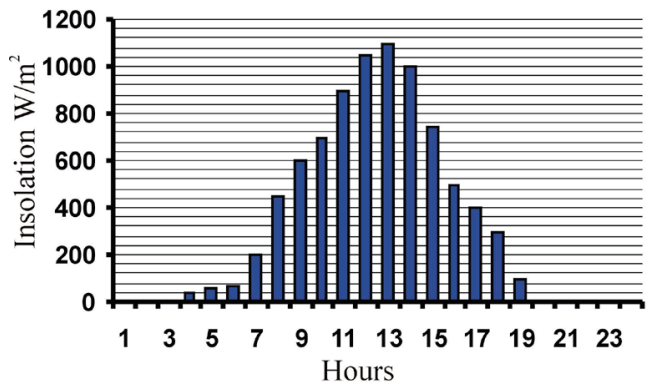

Fig. 2. Lublin city insolation (June) [2]

There are two ways to convert solar radiation into cooling or conditioning of air, based on photovoltaic (PV) panels and solar collectors combined with variety of thermodynamic processes [3]. Techniques allowing use of solar thermal collectors, which are currently prevailing over PV panels for air-conditioning of buildings can be basically divided into thermally driven chillers (to produce chilled water which can be used for any type of air-conditioning) and open cycles, also referred to as desiccant cooling systems (for direct treatment of air in a ventilation system). 
Treatment techniques based on Solar Energy and Advanced Oxidation Technologies (AOTs) create a good alternative for classic treatment options, especially in agricultural applications. AOTs are considered energy-consuming but with supply of electrical energy from solar systems they can be economically justified. Insolation in Europe is also the highest during summer period when most of agricultural crops are produced.

Ozone generated during electrical discharge can be used for removal of both: biological and chemical pollutants. The only product of $\mathrm{O}_{3}$ decomposition is molecular oxygen. Moreover, ozone improves water organoleptic properties such as taste, smell and colour. In the case of groundwater it allows decreasing the amount of carbohydrates, their chlorine derivatives, polycyclic aromatic carbohydrates and nitroaromatic compounds so it can be successfully used for revitalization of contaminated areas.

Non-thermal plasma technologies are currently used during many industrial processes when environmental concerns prevail on disadvantages related to chemical methods for high risk of formation of even more toxic secondary pollutants or imperfection of treatment result.

Advanced Oxidation Technologies using ozone in combination with other strong active species such as hydrogen peroxide, hydroxyl radicals, UV radiation and solar energy allow obtaining synergetic effect. Small water, wastewater, air and soil treatment installations supplied with electric energy from renewable energy sources are perfect example of zero-emission technology achieved with reasonable cost $[4,5]$.

Trials employing usage of electrical discharges, ozone alone or combined with AOTs were performed for the treatment of soil and plants by international research groups [6-14]. Application of AOTs helps to preserve natural structure of the soil, prevents its acidification, leaching and releasing metallic compounds. Because of its relatively good solubility in aqueous phase, ozone generated during electrical discharges seems to be especially potential for the soil treatment because it can be applied in both: gaseous and aqueous phase. Ozone reacts with pollutants directly or decomposes via catalytic reaction with other species (such as metal oxides) present in the environment to form the secondary oxidizing agents: omnipotent hydroxyl radicals [15], ozonide radicals, hydrogen peroxide, perhydroxyl, superoxide, and singlet oxygen [16-18].

There are numerous works covering application of Fenton's Reagent to the soil treatment. Higher $\mathrm{H}_{2} \mathrm{O}_{2}$ concentration provided faster reaction times but less efficient oxidants use [19-21]. Watts et al. [20] reported using of $\mathrm{H}_{2} \mathrm{O}_{2}$ for cleaning soils mentioning main factors influencing efficiency such as availability of iron, buffering capacity and natural humus content.

Our goal is to develop low cost, flexible agricultural technology based on application of environmental friendly oxidants as an alternative to traditional chemical methods. AOTs based decontamination of soil and plants ensures safety and supports organic agricultural production as the secondary pollution by commercial pesticides and fungicides can be avoided. Moreover, in the most of cases (including cold climate of Poland) proposed devices could be powered from renewable energy resources such as solar batteries.

\section{EXPERIMENTAL SET-UP}

Autonomous air/water/soil treatment installation supplied from PV panels was developed in Lublin University of Technology in cooperation with Japanese partners. Set-ups for soil and plants' treatment were extensively described $[6-11,22]$. Fig. 3 depicts proposed integrated ozonation installation that consists of three basic sub-systems: electric energy power system, ozone production system and air/water/soil treatment system. It was designed for a constant work in difficult climatic conditions. The devised technological solution is excellent to be utilized in remote terrains, which are distant from electroenergetic network or in the places where the electroenergetic main is unstable and fallible. Currently, the total cost of generating electrical energy from solar batteries is one order of magnitude higher than in case of nuclear energy. However, the application of solar batteries becomes profitable, as far as the demand for electrical energy is small. The correctly selected system should cover about $95-100 \%$ of electrical energy demand during summer.

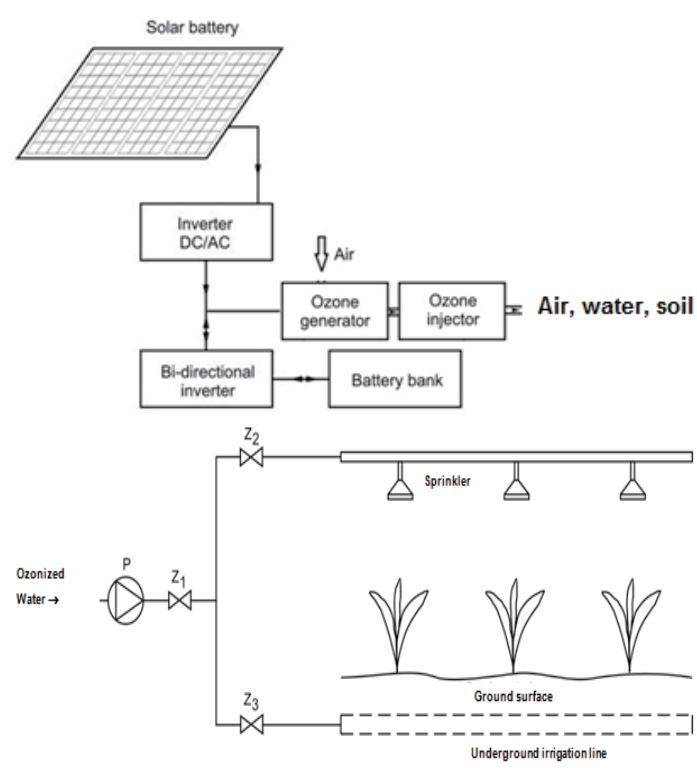

Fig. 3 Integrated systems for ozonation of air, water and soil

In water ozonation sub-system, the appropriately made contact container has a fundamental influence on stability and final quality of the process. In the majority of ozonation systems ozone is added to water in the form of bubbles through diffuser. The effectiveness of such a process is low because ozone is not evenly mixed with water, and when in large quantities, ozone evaporates from water into ozone destructors, from where the unused oxygen is blown out to the atmosphere. To reduce influence of factors mentioned above innovative system developed by company WOFIL was used. In this solution, raw water was initially aerated and oxidized with the oxygen mixed with ozone, which evaporated from the contact container. It enabled the increase of ozonation process' efficiency by almost $30 \%$ (in comparison with the competitive ideas) without the increase of electrical energy consumption. It also 
resulted in reduction of amount of gas which was blown out to ozone destructors and in lower values of residual ozone after the contact container. In order to remove the excess of the produced and the residual ozone the catalytic destructors were used.

The main element of electrical power system is bi-directional inverter, administering loads, the flow of energy and the work of accumulators. Inverter provids $24 \mathrm{~V}$ grid of DC voltage and a typical grid of $\mathrm{AC}$ voltage $110 \mathrm{~V} / 60 \mathrm{~Hz}$ or $230 \mathrm{~V} / 50 \mathrm{~Hz}$. Thus, it enables integration ranging from electric generators to energy receivers.

Moreover, portable ozone-mist sterilization system for agriculture was developed [9]. Ozone was produced by surface dielectric barrier discharge generated on the surface electrode placed on $\mathrm{Al}_{2} \mathrm{O}_{3}$ dielectrics (146x 146 $\mathrm{mm})$. High voltage electrode was embedded inside the dielectric plate and molded. The AC electric power for the high frequency generator $(15 \mathrm{kHz}, \mathrm{Vp}-\mathrm{p}=8 \mathrm{kV})$ was supplied from the AC-DC inverter connected to Li-ion battery. The electrode system was cooled by air. Maximum concentration of $86 \mathrm{~g} / \mathrm{m}^{3}$ was attained at oxygen flow rate of $1 \mathrm{l} / \mathrm{min}$. Water-mist was produced by supplying the water to the mist nozzle. Battery could be charged from PV panels.

\section{EXPERIMENTAL RESULTS}

The reaction with highly concentrated ozone caused the remarkable change in physical and chemical properties of the soil. Rapid temperature increase up to $70{ }^{\circ} \mathrm{C}$ observed in ozone treatment was considered to be due to the chemical exothermic reaction between the soil and the gas-phase reaction. In-situ measurements showed the rapid decrease of the $\mathrm{pH}$ value and gradual increase of the electrical conductivity. The physicochemical properties of treated soil are presented in Tab. 1.

Tab. 1. Soil temperature, EC and $\mathrm{pH}$ in the process of ozone treatment.

\begin{tabular}{llll}
\hline Stage & Temperature & $\mathrm{EC}$ & $\mathrm{pH}$ \\
\hline Initial & $26^{\circ} \mathrm{C}$ & $48 \mathrm{mS} / \mathrm{m}$ & 5.7 \\
$\mathrm{t}=20$ min & $63^{\circ} \mathrm{C}$ & $65 \mathrm{mS} / \mathrm{m}$ & 4.9 \\
$\mathrm{t}=120 \mathrm{~min}$ & $32^{\circ} \mathrm{C}$ & $82 \mathrm{mS} / \mathrm{m}$ & 5.2 \\
\hline
\end{tabular}

Tab. 2. Soil sterilization by in-situ ozone treatment

\begin{tabular}{lc|c}
\hline Untreated [CFU/cc] & \multicolumn{2}{c}{$5.7 \times 10^{6}$} \\
\hline Gas flow rate[ 1/min] & \multicolumn{2}{c}{3} \\
\hline Ozone concentration [ $\left.\mathrm{g} / \mathrm{m}^{3}\right]$ & 10 & 20 \\
Duration [min] & 10 & 10 \\
Ozone treated [CFU/cc] & $1.4 \times 10^{5}$ & $1.7 \times 10^{2}$ \\
Sterilization rate [\%] & 97.5 & 99.9 \\
\hline
\end{tabular}

Conventional biological method of the CFU (colony forming unit) counting showed that harmful Fusarium oxysporum in the soil was almost eliminated by ozone treatment with the concentration over $20 \mathrm{gO}_{3} / \mathrm{m}^{3}$ achieving sterilization rate up to $99.9 \%$. Results of experiment are summarized in Tab. 2.

Experiments on eradication of Red aphid Uroleucon nigrotuberculatum, one of the most detrimental insect pests on cultivated plants in moderate climate region were carried. The initial samples (40-120 aphids) consisted of small larval aphids and large imago aphids. Portable mist spraying system (ozone concentration of $68 \mathrm{~g} / \mathrm{m}^{3}$ with oxygen flow rate of 2 liter/min and water flow rate of $300 \mathrm{ml} / \mathrm{min}$ ) was used.

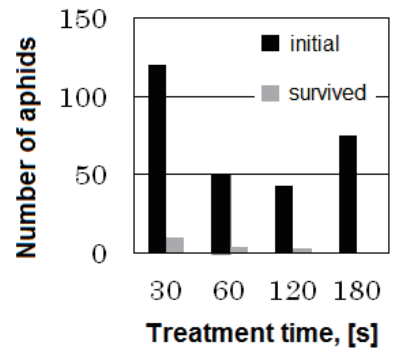

Fig. 4. The survival rate of Red aphid as a function of the treatment time at the distance of $50 \mathrm{~mm}$.

When ozone gas from the ozonizer was injected into the water-mist cloud, the ozone concentration decreased to $6.8 \mathrm{~g} / \mathrm{m}^{3}(3200 \mathrm{ppm})$ at the exit and to $8.4 \mathrm{ppm}$ at $50 \mathrm{~mm}$ distance from the nozzle. The survival rate was about $8 \%$ at the short treatment time till $60 \mathrm{sec}$ and then decreased gradually with increasing time. Long sterilization time of $180 \mathrm{sec}$ is needed to kill the large aphids. Results of carried experiments with different initial number of aphids for each treatment time are depicted in Fig.4.

In the experiment, drinking water to produce water-mist had $\mathrm{pH}$ value of 7.1 and the ozonized water from ozone-mist cloud had average $\mathrm{pH}$ value of 7.7 and ozone concentration of $1.5 \mathrm{ppm}$. The fact that at the treatment time of $30 \mathrm{sec}$ the survival rate of ozone-mist treatment is lower than in the case of ozone gas spraying is considered to be mostly due to existence of reactive radicals having strong oxidation power in ozone-mist. The ozone and its derivative radicals such as ${ }^{*} \mathrm{O}_{2}{ }^{-},{ }^{*} \mathrm{HO}_{2}$, $* \mathrm{OH},{ }^{*} \mathrm{O}_{3}{ }^{-}$enter the respiratory system of the aphid and give fatal damage.

Tab. 3. Effect of ozone treatment on plant growth

\begin{tabular}{|l|l|l|l|l|}
\hline \multicolumn{3}{|c|}{ Chinese cabbage } & \multicolumn{2}{c|}{ Spinach } \\
\hline days & ozone & $\begin{array}{l}\text { none } \\
\text { ozone }\end{array}$ & ozone & $\begin{array}{l}\text { none } \\
\text { ozone }\end{array}$ \\
\hline 7 & small & large & large & small \\
\hline $12-15$ & small & large & large & small \\
\hline $25-27$ & small & large & large & small \\
\hline 39 & same & same & large & small \\
\hline 50 & same & same & large & small \\
\hline 79 & small & large & large & small \\
\hline
\end{tabular}

Seedlings and seeds of Chinese cabbage (Brassica pekinensis), Garland chrysanthemum (Chrysanthemum coronarium), muskmelon (Cucumis melo), tomato (Solanum lycopersicum) and spinach (Spinacia oleracea) were placed in separated containers with pre-ozonized soil (after 23 days from ozonation, $\mathrm{pH}=5$ ) and with non-ozonized soil, respectively. Soil ozonation influenced plants' growth in various ways (Tab.3). There 
was $24 \%$ of growth inhibition after 79 days in the case of cabbage due to decreasing $\mathrm{pH}$ of soil and parallel elimination of microorganisms useful for soil enrichment. Improvement of growth was observed in the case of melons and tomatoes, for which environmental stress has a beneficial influence on growth and fruit formation. After the mist spraying damage of the leaves in tomato and eggplants was observed.

\section{CONCLUSIONS}

The presented air/water/soil ozonation set-ups are currently being prepared for implementation procedures. They could be easily adjusted to individual needs. Power from PV panels could cover up to $95-100 \%$ energy needs in summer period in optimized integrated system. Efficiency of ozone application and AOT methods for water is already well known. Ozone usage in the case of soil allowed achieving $99.9 \%$ sterilization efficiency in the case of Fusarium oxysporum at the ozone dosage over $20 \mathrm{gO}_{3} / \mathrm{m}^{3}$. Portable ozone-mist spray system for control of harmful insects in agricultural management was developed. In the case of Red aphids, the survival rate was $8 \%$ at treatment time till $60 \mathrm{sec}$ and then rapidly decreased with treatment time. However, ozone-mist treatment in used conditions also gave biological damage on leaves of the plants.

\section{REFERENCES}

[1]K. Nalewaj, T. Janowski, Z. Złonkiewicz, ISES Solar World Congress, Goteborg, Sweden (2003)

[2] www.helpsavetheclimate.com/insoleurope.html, Energie-Atlas GmbH, CH-4142, Munchenstein.

[3]H. Henning, Applied Thermal Engineering, 27, 1734-1749 (2007)

[4]J. Pawłat, H. Stryczewska, Application of Solar Energy in the Processes of Gas, Water and Soil Treatment, edited by Radu D. Rugescu, chapter 7, INTECH (2012)

[5]J. Pawłat, J. Diatczyk, G. Komarzyniec, T. Giżewski, H. Stryczewska, K. Ebihara, F. Mitsugi, S. Aoqui, T. Nakamiya. Proc. International Conference on Computer as a Tool (EUROCON), Lisboa, Portugal (2011)
[6] J. Pawłat, H. Stryczewska, K. Ebihara, Journal of Advanced Oxidation Technologies, 13(2), 138-145 (2010)

[7]H. Stryczewska. J. Pawłat, K. Ebihara Journal of Advanced Oxidation Technologies, 16(1), 23-30 (2013)

[8]K. Ebihara, H. Stryczewska, T. Ikegami, F. Mitsugi, J. Pawlat, Electrical Review, 87(7), 148-152 (2011)

[9] K. Ebihara, F. Mitsugi, T. Ikegami, N. Nakamura, Y. Hashimoto, Y. Yamashita, S. Baba, H. Stryczewska, J. Pawłat, S. Teii, T. Sung, EPJAP, 61(2), 24318 (2013)

[10] H. Stryczewska, T. Giżewski, J. Pawłat, T. Jakubowski, S. Kalisiak, Journal of Advanced Oxidation Technologies, 16(1), 52-62 (2013)

[11] K. Ebihara, H. Stryczewska, F. Mitsugi, T. Ikegami, T. Sakai, J. Pawłat, S. Teii, Electrical Review, 88(6), 92-94 (2012)

[12] G. Raniszewski, Z. Kolaciński, L. Szymanski: Journal of Advanced Oxidation Technologies, 15(1), 34-40 (2012)

[13] G. Raniszewski, Z. Kolaciński, L. Szymanski: Electrical Review, 88(8), 1-5 (2012)

[14] S. Kitazaki, K. Koga, M. Shiratani, N. Hayashi, Jpn. J. Appl. Phys., 51, 01AE01-1 - 01AE01-4 (2012)

[15] H. Glaze, J. Kang, J.AWWA, 80(5), 57-63 (1988)

[16] A. Voloshin, G. Sharipov, V. Kazkov, G. Tolstikov, Bulletin of the Academy of Sciences of the USSR Division of Chemical Science, 35(11), 2397-2399 (1986)

[17] G. Gordon, B. Bubnis, Ozone: Science and Engineering, 21(5), 447-464, (1999)

[18] U. Jans, J. Hoigné, Atmospheric Environment, 34(7), 1069-1085 (2000)

[19] www.H2O2.com.

[20] R. Watts, M. Udell, P. Rauch, S. Leung, Hazardous Waste and Hazardous Materials, 7(4), 335-345 (1992)

[21] J. Watts, Remediation, 2(4), 413-425 (1992)

[22] J. Pawłat, H. Stryczewska, K. Ebihara, F. Mitsugi, S. Aoqui, T. Nakamiya, Proc. HAKONE XII, Trenčianske Teplice, Slovakia, 2010, 407-411 (2010)

(Received April 6, 2013; Accepted February 28, 2014) 